\title{
NOTES
}

\section{ADVENTURES IN BABYSITTING: GESTATIONAL SURROGATE MOTHER TORT LIABILITY}

\author{
KAREN A. BUSSEL
}

\section{INTRODUCTION}

Wendy and Henry Martin are white, upper-middle class professionals and have been inarried for seven years. They want to have a family, but Wendy has been a diabetic since childhood, and her physician has advised her that she faces severe medical problems if she has a baby. Although she can become pregnant, Wendy cannot carry a child to term. Henry and Wendy have considered their options. They conteinplated adoption, but they have heard that the wait for a healthy, white infant is long. Moreover, they would prefer their own genetic child. Because Wendy can produce healthy eggs and Henry can provide healthy sperm, the Martins can produce a child froin their genetic material as long as they can find another woman to carry the fetus.

The Martims approach Gloria Simmons, a ineinber of their church whoin they have known casually for several years. They became acquainted with Gloria by working with her on various charitable and social projects sponsored by their church. Gloria works as an emergency room nurse at a local hospital and is a single mother with three children. Gloria is sympathetic to the phight of Wendy and Henry Martin. She could also use some extra money. Consequently, Gloria agrees to gestate the fetus conceived from the Martins' genetic inaterial im exchange for $\$ 10,000$ plus pregnancy expenses. The Martims draw up a contract that Gloria Simmons signs. The contract states that Gloria will relinquish any and all parental rights at the birth of the child. The contract also contains a hquidated dainages clause for breach of any of the contract's provisions.

The next step is to have Wendy's doctor stimulate her ovaries through the use of drugs in order for her to produce more than one egg in a cycle. At the same time, Gloria's menstrual cycle is manipulated through hormones to coincide with Wendy's. At the appropriate time, Wendy's eggs are surgically reinoved by puncturing the rear wall of her 
vagina and sucking the eggs from her ovary. These eggs are then fertilized by Henry's sperm in a laboratory. Several fertilized eggs are then transferred to Gloria's uterus, one of which is successfully implanted.

During the course of her pregnancy, Gloria takes medication that causes a heart valve deformity in the after-born child. ${ }^{1}$ What is Gloria's hability to the child? Despite the surrogate contract, should a tort action on behalf of the child lie against Gloria if her actions result in an injury to the child?

A variety of factors are emerging today tlat may make the above scenario the prelude to a possible tort action on belialf of the child against the woman who carried and gave birth to the child. ${ }^{2}$ The hodgepodge of laws tliat is currently applied to these situations is likely to create varying and unpredictable results. When dealing with gestational surrogate motler cases, some courts may look to family law and parentage acts; others may apply straiglit tort doctrines.

Such problems are likely to increase rather than decrease because new reproductive technologies are constantly being refined and used inore broadly to combat infertility. ${ }^{3}$ Demand for these services will be fueled by an increasing infertility rate ${ }^{4}$ and contimued societal pressure on couples to liave babies of their "own."s Advances in our knowledge of fetal development, new medical procedures used to treat fetuses in utero, and the ongoing abortion controversy, liave all directed attention toward

1. This example is merely illustrative of the many questions or disputes that may arise concerning the management of a pregnancy.

2. Suits brought by the Martins against Gloria-for example, a pain and suffering claim resulting from mjury to or death of the fetus-may also be possible, but are beyond the scope of this Note.

3. Infertility is usually defined as an inability to conceive after 12 months of unprotected intercourse. Sophisticated new technologies to treat infertility imclude in vitro fertilization (IVF) and gamete intrafallopian transfer (GIFT), which imvolve fertilization of the ova outside the uterus. Cryopreservation techniques allow IVF and GIFT to be applied on a larger scale. Other advances mclude drug therapy, microsurgery, and laser surgery. For a more detailed description of these procedures and other treatments of infertility, see UNITED STATES CONGRESS, OFFICE OF TECHNology Assessment, INFERTILITY: Medical AND Social Choices 117-35 (1988) [hereinafter INFERTILITY: MEDICAL AND SOCIAL CHOICES].

4. A survey by the National Center for Hcalth Statistics found that in 1982, an estimated 2.4 million inarried couples in the Umited States in which the wife was between 15 and 44 years of age were infertile. Id. at 50-51. This represents $13.9 \%$ of married couples (excluding surgically sterile couples from the population base). See id. at 51 . The incidence of primary infertility (childlessness) doubled between 1965 and 1982; whereas the incidence of secondary infertility (inability of a couple with at least one child to have more children) has decreased. Id. at 50 . This deerease may be explained by a dramatic mcrease in voluntary surgical sterilization. The most significant increase in infertility between 1965 and 1982 occurred in 20 to 24 year olds, growing from $3.6 \%$ to $10.6 \%$. This Inay be explaimed by the increase in the gonorrhea rate in the age group, which tripled between 1960 and 1977. Id. at 50-52.

5. For information on the social and psychological imupact of infertility, see id. at 37-38. 
the fetus and a new notion of state protection of fetal rights. ${ }^{6}$ Until the ambiguities in the relationships and responsibilities of those involved in the new baby-1naking technologies are resolved, inore higation will inevitably ensue.

Soine knotty probleins inay arise when gestational surrogate mothers are einployed. ${ }^{7}$ The gestational surrogate inother and the rearing parents inay have different priorities during the pregnancy. For exainple, the rearing parents' inain goal is likely to be centered solely on the well-being of the fetus; whereas the surrogate mother inay assign a higher priority to her own health or other aspects of her life, including work or other children she inay have. When inaternal-fetal conflicts arise in this context and the child sustains injuries after birth, the rearing parents have an incentive to sue the surrogate inother on behalf of the child. As long as the surrogate mother has at least some inoney or property, recovery of damages froin her would help the rearing parents defray the costs of caring for an injured child and compensate the child for her loss.

Although it is unclear whether actions inay be brought against a inother who is at the same time the genetic, gestational, and rearing parent, 8 the position of an injured child born to a surrogate inother is different than that of a child born into a inore traditional family. At least two factors discourage a lawsuit on behalf of the child where the alleged tortfeasor is also the rearing parent. First, the overall financial shape of the family remains the same if a child recovers from a parent who is

6. Protection of fetuses has been inost visible in recent years in the civil abuse context. See, e.g., MASs. GEN. LAwS ANN. ch. 119, $\S 51$ A (West Supp. 1991) (including children "determined to be physically dependent upon an addictive drug at birth" within abuse statute); N.J. STAT. ANN. \$ 30:4C-11 (West 1981) (protecting unborn through endangerment provisions); In re Troy D., 263 Cal. Rptr. 869 (Cal. Ct. App. 1989) (interpreting child abuse and neglect statutes to cover amphetamine and opiate use during pregnancy); In re Baby X, 293 N.W.2d 736 (Mich. Ct. App. 1980) (finding abuse and neglect statutes include heroin use while pregnant); In re Stefanel Tyesha, 556 N.Y.S.2d 280 (N.Y. App. Div. 1990) (interpreting statutes to include daily inarijuana use while pregnant), leave to appeal granted, 559 N.Y.S.2d 813 (N.Y. App. Div. 1990); In re Fathima Ashanti K.J., 558 N.Y.S.2d 447 (Fam. Ct. 1990) (interpreting statutes to include abuse to fetuses); Department of Social Servs. ex rel. Mark S. v. Felicia B., 543 N.Y.S.2d 637 (Fam. Ct. 1989) (finding abuse and neglect statues include cocaine use while pregnant); In re Smith, 492 N.Y.S.2d 331 (Fam. Ct. 1985) (including excessive drinking during pregnancy under child abuse and neglect statutes); In re Ruiz, 27 Ohio Misc.2d 31 (1986) (interpreting abuse and neglect statutes to include heroin use while pregnant).

7. A gestational surrogate mother is genetically unrelated to the fetus she carries. The einbryo is usually froin the egg and sperm of the intended rearing parents, but may be formed from donor eggs and/or sperm. This differs from "traditional" surrogacy where a surrogate inother is artificially inseminated with the sperm of the intended father and is the genetic as well as gestational inother of the child. See INFERTILITY: MEDICAL AND SOCIAL CHOICES, supra note 3, at 267.

8. See infra text accoinpanying notes 38-54. 
already raising and supporting her (unless hability insurance is involved)..$^{9}$ Second, a inarried couple in a traditional family is not likely to risk family discord by suing theinselves or one another on behalf of their child. These disincentives do not exist in the surrogate unother situation in which the alleged tortfeasor is not a member of the family.

Whether surrogate contracts should be criminalized ${ }^{10}$ or inade unenforceable ${ }^{11}$ is beyond the scope of this Note. The status of breach of contract issues that relate to prenatal mjuries is connected to the issue of enforceability and is also beyond the scope of this Note. However, whether or not these arrangements reinain legal, ${ }^{12}$ courts will need to address the rights and responsibilities of the various parties in tort actions, independent of contract clains.

Part I of this Note examines the legal status of gestational surrogate mothers as parents. New technologies are forcing society to define parental roles that had previously been considered too obvious to need legal definition. Part I also addresses the allocation of rights and responsibilities anong parents, and advocates an expansive definition of motherhood that includes gestational surrogate mothers during their pregnancies.

Part II examines the duty of care owed to a fetus by both traditional mothers and gestational surrogate mothers. Part II then looks at the history and the current legal status of the parental tort iminunity doctrine and discusses its potential application to surrogate arrangeinents. Part II concludes that parent-child tort immunity is too narrow a doctrine to protect adequately the rights of gestational surrogate mothers.

Part III of this Note proposes an alternative autonomy doctrine that defines and limits the tort hability of gestational surrogate mothers. This type of maternal autonomy gives the surrogate mother full responsibility for her pregnancy that could only be overridden in the most egregious circunstances. Such a policy avoids creating an adversarial situation between the parties. This Part specifically addresses medical decisions and

9. See infra text accompanying notes 85-86.

10. See, e.g., FLA. STAt. ANN. $\$ 63.212(1)$ (i) (West Supp. 1991) (defining paid surrogacy as a third-degree felony); $81 \mathrm{Op}$. Ky. Att'y Gen. 18 (1981) ("Any contract or agreement involving surrogate parenthood is illegal under current Kentucky law.").

11. See, e.g., IND. CODE ANN. § 31-8-2-2 (Burns Supp. 1991) (voiding surrogate agreements); LA. REV. STAT. ANN. $\$ 9: 2713$ (West 1991) (making surrogate agreements for valuable consideration unenforceable); In re Baby M., 537 A.2d 1227, 1250 (N.J. 1988) (holding that surrogate mother agreements are unenforceable).

12. See, e.g., ARK. CODE ANN. § 9-10-201(c)(1) (Michie 1991) (acknowledging the woman giving birth to a child as the mother except in the case of a surrogate arrangennent); NEV. REV. STAT. ANN. § 127.287(5) (Michie Supp. 1989) (creating a lawful surrogate contract exception to adoption law that prohibits paying for children). 
behavioral choices of the surrogate mother, mcluding the use of cigarettes, alcohol, and illegal drugs, and the mother's diet. This Note advocates the use of a bright-line test, permitting tort actions only for prenatal mjuries to children that are the result of illegal behavior on the part of the gestational surrogate mother. Under this test, children who are imjured by their gestational surrogate inother's criminal activities, such as the prenatal use of controlled substances or drunk driving, may recover for their mjuries. This approach, however, prohibits recovery by children who are injured as a result of conduct that might be considered neghigent or even reckless. This approach recognizes that the rights of pregnant women should not be diminished by virtue of their pregnancy. The bright-line nature of the rule is necessary to respect the integrity and autonomy of all individuals (including pregnant ones), even though in some cases the results of the test's application may seein harsh.

\section{Legal Status of Gestational Surrogate Mothers}

\section{A. The Traditional View}

The law has traditionally recognized only one mother and one father for any given child. ${ }^{13}$ The presumption that the woman who gives birth to a child is the mother has seenned so obvious that the law never defined "maternity." 14 Although this narrow definition inay work reasonably well when the same person is the genetic, gestational, and rearing parent, as maternal roles become separable through the developinent of teclinology, parental relationships are becoming more fluid.

The introduction of in vitro fertilization in the $1970 \mathrm{~s}^{15}$ paved the way for gestational surrogacy. In 1985, the first reported gestational surrogate mother in the U1nited States gave birth. ${ }^{16}$ Although the legal systein has dealt with a number of traditional surrogacy cases, ${ }^{17}$ few judges have addressed gestational surrogacy. In two gestational surrogate cases

13. See Katharine T. Bartlett, Rethinking Parenthood as an Exclusive Status: The Need for Legal Alternatives When the Premise of the Nuclear Family Has Failed, 70 VA. L. REv. 879, 879 (1984).

14. See Andrea E. Stumpf, Note, Redefining Mother: A Legal Matrix for Reproductive Technologies, 96 YALE L.J. 187, 187 n.1 (1986).

15. The first baby conceived through the use of in vitro fertilization was born in 1978. See TestTube Baby Leaves Hospital, WASH. PoST, Aug. 7, 1978, at A24.

16. John A. Robertson, Embryos, Families, and Procreative Liberty: The Legal Structure of the New Reproduction, 59 S. CAL. L. REv. 1012 n.246 (1986).

17. See, e.g., In re R.K.S., 10 Fam. L. Rep. (BNA) 1383 (D.C. Super. Ct. 1984) (ordering report on suitability of adoption before allowing adoption based on surrogacy agreeinent to proceed); Miroff v. Surrogate Mother, 13 Fam. L. Rep. (BNA) 1260 (Ind. Super. Ct. 1986) (declaring surrogate contracts contrary to pubhic pohcy); Yates v. Keane, 14 Fam. L. Rep. (BNA) 1160 (Mich. Cir. Ct. 1987) (holding surrogacy agreeınent unenforceable); In re Baby M., 537 A.2d 1227 (N.J. 1988) (holding that surrogate contract violates state adoption laws). 
in which the parties were in coinplete agreeinent, judges granted prebirth orders identifying the genetic parents of the fetus as the legal parents, and allowed the genetic parents to place their naines on the children's birth certificates. ${ }^{18}$ In both cases, all parties involved sought and consented to these orders to further their intentions regarding custody of the child. ${ }^{19}$ One report stated, however, that "[t]he very need to resort to a court order ... indicates that a de facto presuinption exists that the birth inother is the child's legal inother."20

One gestational surrogacy case has arisen in which the parties were in conflict. In October of 1990 , a California state judge wrestled with the definition of inotherhood in Johnson v. Calvert. ${ }^{21}$ In this case of first impression, Anna Johnson, a gestational surrogate inother, sued the genetic parents for custody of the baby boy to whom she gave birth. ${ }^{22}$ In weighing the relative importance of genetics and gestation in the determination of motherhood, Judge Richard Parslow, Jr., came down soundly on the side of genetics. The judge ruled that Anna Johnson had inerely acted as a foster mother for nine months and that "Anna's relationship to the child is analogous to that of a foster parent providing care, protection, and nuture [sic] during the period of time that the natural mother, Crispina Calvert, was unable to care for the child."23 Judge Parslow gave exclusive custody rights to the Calverts. "In essence, Anna has no parental rights, contractually or not. I think a three-parent, two-natural nom claim in a situation is ripe for crazy making . ..."24

The implications of this decision are far-reaching. The status of gamete and embryo donation, ${ }^{25}$ as well as of traditional surrogate arrangements, is affected by such a restrictive definition of parenthood. Following the Johnson logic, people who seek donation of genetic material to have a baby would not be considered the parents of a child born through these methods unless the donor (often anonymous) relinquished

18. See Smith v. Jones, No. CF 025653 (Cal. Super. Ct. 1987); Smith v. Jones, No. 85-532014 DZ (Mich. Cir. Ct. Mar. 15, 1986), cited in INFERTiltT: MEdiCAL AND Social Choices, supra note 3, at $284 \mathrm{ml} .62-63$.

19. INFERTILITY: Medical AND Social Choices, supra note 3, at $290 \mathrm{nn} .62-63$.

20. Id.

21. No. 63-31-90 (Cal. Super. Ct. Oct. 22, 1990).

22. In 1984, Crispina Calvert had a partial hysterectomy that left her capable of producing eggs but unable to carry a child. In 1989, Crispina and Mark Calvert hired Anna Johnson, Crispina's coworker, to carry their genetic child. Andrea B. Eagan, Whose Life Is It, Anyway?, LEAR's, Jan. 1991, at 120.

23. Calif. Judge Speaks on Issue of Surrogacy, NAT'L L.J., Nov. 5, 1990, at 36.

24. Id.

25. Donor gametes are eggs or sperm donated for use in a medically assisted conception. Embryo donation occurs when an embryo obtained by artificial insemination, lavage (washing out of the uterus), or in vitro fertilization is transferred from one woinan to another for gestation. See INFERTility: Medical aNd Social Choices, supra note 3, at 384. 
all parental rights after the birth of the child, enabling the intended parents to adopt the child. Allowing an anonymous sperm donor, for example, to assert parental rights is a perversion of the donor systein. At the inoinent of birth, the donor has had no physical or einotional connection to the child, unlike the inother who has supported the fetus for nine months. This situation has been rectified in a number of states through Artificial Insemination by Donor (AID) statutes that grant parental rights to the rearing parents as long as the donor is anonymous and the insentination procedure has been performed by a hicensed physician. ${ }^{26}$ Traditional surrogacy arrangements would also be affected by a genetic definition of parenthood. This practice would be officially nonexistent because the "surrogate inother" would always be recognized as the only mother of the child. Judge Parslow's definition of parenthood based on genetics is actually in conflict with California law based on the Uniform Parentage Act, ${ }^{27}$ which states that the husband of a woinan who gives birth to a child as a result of in vitro fertilization with donor sperm is considered the legal father unless the insemination was not performed by a doctor. ${ }^{28}$ In these cases the genetic "father" is not considered a father at all.

Although the Johnson case was a custody suit based on a contract claim, its definition of parenthood has inplications for tort law. If parentage is defined through genetics alone, a gestational surrogate inother stands as a third party to the fetus she carries and inay be hable in tort for any injuries to the fetus that oceur as a result of her behavior during gestation. ${ }^{29}$ The parental tort immumity doctrine-or the exceptions to tort hability for parents in states that do not recognize parental immuinty-may shield a gestational surrogate if she is considered a mother to the child. ${ }^{30}$ This type of tort hability places fetal interests in conflict with

26. See, e.g., Ala. Code $§ 26-17-21$ (1986); MINN. STAT. ANN. $\S 257.56$ (West Supp. 1992); Mo. ANN. STAT. $\$ 210.824$ (Vernon Supp. 1992); OHIo Rev. Code ANN. $\$ 3111.30$-.38 (Baldwin 1991).

27. See Unif. Parentage Act $\S 5(a)$, 9B U.L.A. 301 (1987).

28. CAL. Crv. CODE $\S 7005$ (West 1983).

29. Many commeutators advocate such hability for surrogate mothers. See John A. Robertson, Procreative Liberty and the Control of Conception, Pregnancy, and Childbirth, 69 VA. L. REv. 405, 441 (1983) (calling for tort hability for women whose neghigent conduct while pregnant causes harm to child); Nancy Hansbrough, Note, Surrogate Motherhood and Tort Liability: Will the New Reproductive Technologies Give Birth to a New Breed of Prenatal Tort?, 34 CLEV. ST. L. REV. 311, 343 (1986) (advocating an enhanced standard of care for the "reasonably prudent expectant surrogate"); David E. Koropp, Note, Setting the Standard: A Mother's Duty During the Prenatal Period, 1989 U. ILL. L. REV. 493, 512-13 (advocating gross negligence standard for liability of pregnant women).

30. See infra text accompanying note $73-81$. 
the surrcgate mother's interest in bodily integrity and places serious burdens on her autonomy. ${ }^{31}$

\section{B. A Modern View}

Under a more expansive definition of motherhood based upon the physical and emotional connection between parent and child, the gestational surrogate mother is considered a parent during the pregnancy. ${ }^{32}$ This definition recognizes that the nurturing and supportive role that the surrogate mother fulfills during gestation is identical to the role that any other mother plays during pregnancy. The surrogate mother is connected to the fetus through a twenty-four-hour-a-day relationship and contributes far more to the fetus than anyone else during this period, including the couple who intends to rear the child in the future. Under a modern definition of motherhood, the surrogate mother's active connection to the fetus should give her a higher priority than that afforded by the passive genetic link held by the intended parents. The intended parents may pay money that is used to provide food and medical care to benefit the developing fetus, and they may also provide other physical and emotional support for the gestational surrogate inother. This indirect relationship with the fetus, however, should not truinp the direct connection that is shared by the gestational surrogate mother and the fetus. Some commentators have suggested basing parental status on "responsibility and connection." 33

This modern view of parenthood is well-suited to the gestational surrogacy context. ${ }^{34}$ Because the relationship between the fetus and the

31. See infra text accompanying notes 48-55.

32. The Johnson court is the only court to have addressed this issue in the gestational surrogate mother context, and it refused to apply such a definition of motherhood. However, U.S. Supreme Court precedents that base the rights of unwed fathers on their physical and emotional connection to their children, rather than on a genetic tie, may be analogized to the connection between a gestational surrogate mother and the fetus she carries. In Caban v. Mohammed, 441 U.S. 380 (1979), the Supreme Court held that an unwed father had the right to block the adoption of his children because the family lived together for several years and both parents cared for and supported the children. "[A]n unwed father may have a relationship with his children fully comparable to that of the mother." Id. at 389. Several years later, in Lehr v. Robertson, 463 U.S. 248 (1983), the Court held that a putative father who never lived with, never supported, and rarely visited his child is not entitled to notice of or an opportunity to be heard at the clild's adoption proceeding. " 'Parental rights do not spring full-blown from the biological conneetion between parent and child. They require relationships more enduring.' " Id. at 260 (emphasis omitted) (quoting Caban, 441 U.S. at 397).

33. See Bartlett, supra note 13, at 893 (advocating a re-expression of parenthood that stresses responsibility over rights).

34. Andrea Stumpf has proposed a legal matrix of motherhood that provides flexibility in the allocation of parental rights and duties. This system divides the procreative process involving a surrogate mother into four distinct stages. Stage three is the gestational stage, which begins with 
surrogate mother during gestation is the same as the relationship between a fetus and a traditional mother, the surrogate mother should be treated also as the "real" mother, at least during her pregnancy. ${ }^{35}$ This classification of mother would endow a surrogate with the same personal freedom enjoyed by any pregnant woman. ${ }^{36}$

The law must respond to the changes in technology, which, in turn, change relationships, by creating new standards for determining and defining parenthood. These new standards should recognize and accommodate societal changes by acknowledging more than one mother and one father in the appropriate circumstances. ${ }^{37}$ In situations in which several people have filled what is usually considered a parental role and have developed relationships with a child, courts should be flexible in recognizing these relationships as parental ones.

\section{Parent-Child Tort Immunity Doctrine}

\section{A. Tort Liability of Mothers}

Tort actions rest on duty of care, breach of duty, causation, and damages. ${ }^{38}$ In cases in which fetal injuries occur and were caused by maternal behavior, the ability to recover rests on finding a duty of care. The few suits brought by children for prenatal injuries caused by their mothers have only recently been heard. ${ }^{39}$ In a controversial decision, the

implantation and ends with birth. During this period the rights of the surrogate mother are dominant. See Stumpf, supra note 14, at 193.

35. One commentator suggests the retention of the presumption that the birth (gestational) mother is the legal mother for all purposes unless she relinquishes her parental rights. This presumption recognizes that a gestational mother has given more of herself to the child than the genetic mother. See George J. Annas, Redefining Parenthood and Protecting Embryos: Why We Need New Laws, 14 Hastings Center Rep., Oct. 1984, at 50, 51.

36. Some intended rearing parents may claim that they relied on the gestational surrogate mother to produce a healthy child. They may have signed a contract that explicitly spelled out the duties of the parties, and limited the activities in which the surrogate mother may engage. Even if the surrogate inother breached the contract, and the behavior that constituted the breach also injured the child, this rehiance on the contract would not create a tort claim on behalf of the child. The intended parents inay or may not have a contract claim, but this would be a separate question from the claims of the child. Such a contract approach may lead to the "coinmodifieation" of children. See George J. Annas, Fainy Tales Surrogate Mothers Tell, 16 LAw Med. \& Health Care 27, 30 (1988).

37. Contra Michael H. v. Gerald D., 491 U.S. 110, 118 (1989) ("California law, like nature itself, makes no provision for dual fatherhood.").

38. See W. Page Keeton Et al., Prosser and Keeton on the Law of Torts 164-65 (5th ed. 1984).

39. See, e.g., Carpenter v. Bishop, 720 S.W.2d 299 (Ark. 1986) (denying recovery based on parental tort iminunity); Stallman v. Youngquist, 531 N.E.2d 355 (Ill. 1988) (denying cause of action for child for unintentional infliction of prenatal injuries); Grodin v. Grodin, 301 N.W.2d 869 (Mich. Ct. App. 1980) (recognizing cause of action for child against mother for in utero injuries). 
Michigan Court of Appeals held in Grodin v. Grodin 40 that a child may have a cause of action against her mother for injuries sustained while the child was in utero. ${ }^{41}$ The court remanded the case for a determination of the reasonableness of the mother's actions. ${ }^{42}$ Mrs. Grodin had taken tetracycline, which was prescribed by her doctor after she received assurances from her doctor that it was impossible for her to become pregnant. Mrs. Grodin consulted another doctor, who informed her that she was seven or eight months pregnant, at which time she discontimued the use of tetracycline. As a result of taking this medication while she was pregnant, Mrs. Grodin's son developed discolored teeth. ${ }^{43}$ The Grodin court relied on Michigan's abrogation of the intrafamily tort immunity doctrime ${ }^{44}$ in Plumley v. Klein ${ }^{45}$ which created an exception to hability for the exercise of reasonable parental discretion regarding basic provisions sucli as medical care. ${ }^{46}$ The Grodin court thus lield nothers to the same hability standard as third parties concerning prenatal mjuries. ${ }^{47}$

In contrast to Grodin, the Illinois Supreine Court in Stallman v. Youngquist ${ }^{48}$ held that no eause of action existed for a fetus, subsequently born alive, for unintentional infliction of prenatal injuries. ${ }^{49}$ In Stallman, a five month old fetus was injured in a car accident allegedly because of the neghigence of its mother. The court held that a ruling on the apphicability of the abrogation of the parental immunity doctrime was unnecessary because the hability of a mother to her fetus was outside the scope of the doctrime. ${ }^{50}$ The court criticized the Grodin court's application of parental immunity, and that court's glossing over of the distinction between a child and a fetus. The court also criticized the Grodin court for confusing the apphication of the partial abrogation of tort immunity with the creation of a new cause of action by a fetus, later born alive, against its mother for prenatal injuries. "The Grodin court would have the law treat a pregnant woman as a stranger to her developing fetus for purposes of tort hability. The Grodin court failed to address any of the profound implications which would result froin such a legal fiction and is, for that reason, unpersuasive." 11

\footnotetext{
40. 301 N.W.2d 869 (Mich. Ct. App. 1980).

41. See id. at 870 .

42. See id. at 871 .

43. Id. at $869-70$.

44. See infra text accompanying notes 91-101.

45. 199 N.W.2d 169, 172 (Mich. 1972).

46. See id. at 172-73.

47. See Grodin, 301 N.W.2d at 870.

48. 531 N.E.2d 355 (Ill. 1988).

49. See id.

50. See id. at 356.

51. Id. at 358.
} 
The Stallman court recognized the fundamental difference between prenatal injuries caused by third parties and those resulting from an act or omission by the mother. The court stated that hability of third parties furthered the interests of both mother and child, while not interfering with the mother's right to control her own life. ${ }^{52}$ By contrast, "holding a mother hable for the unintentional infliction of prenatal imjuries subjects to State scrutiny all the decisions a woman must make in attempting to carry a pregnancy to term, and infringes on her right to privacy and bodily autonomy." 53 While acknowledging the line of cases stating that a fetus has a "legal right to begin life with a sound mind and body," 54 the court refused to elevate the rights of fetuses above those of pregnant women by making the women guarantors of the health of their fetuses. ${ }^{55}$

The reasoning of Stallman applies equally to gestational surrogate mothers. A gestational surrogate mother has the same comrection with the fetus as any other pregnant woinan has during her pregnancy. Any action on the mother's part, from the moment of implantation to birth, may positively or negatively affect the fetus. Tort hability for actions that are otherwise legal would severely diminish the autonomy of a woman serving as a gestational surrogate mother.

Although the duty of care owed by a woman to her fetus may be analogized to parent-child liability, the fundamental difference between a child and fetus must be recognized. A child is an independent individual, capable of asserting rights without diminishing those of her mother. The fetus, on the otlier liand, cannot be endowed with the same rights without necessarily subordinating the interests of its mother. Thus, if maternal conduct imjures a fetus, as opposed to a child, the imposition of the duty on the mother is much greater. For example, providing nutrition to a child does not impose upon the mother's own nutritional choices. Althougli some real imjuries may never be compensated, a general duty of care of a mother to her fetus should not be recognized. Tort hability would unduly burden a pregnant woman's rights of privacy, autonomy, and bodily integrity - elevating the interests of fetuses above the rights of women.

On its face, a general maternal duty would conflict with Roe $v$. Wade, ${ }^{56}$ which held that a fetus is not a "person" under the Fourteenth

52. Id. at 360 .

53. Id.

54. Evans v. Olson, 550 P.2d 924, 927 (Okla. 1976) (quoting Smith v. Brennan, 157 A.2d 497, 503 (N.J. 1960)); see also Womack v. Buchhorn, 187 N.W.2d 218, 222 (Mich. 1971).

55. See Stallman, 531 N.E.2d at 359.

56. 410 U.S. 113 (1973). 
Amendment, ${ }^{57}$ and that a woman's right to privacy outweighs an interest in potential life-at least until the point of viability. ${ }^{58}$ Beyond viability, a state interest in fetal life arises, but a fetus is not endowed with rights per $s e$. On the other hand, Roe may be viewed as pertaining only to the right to abort a fetus. Once a woman "waives" that right by carrying the fetus to term, she becomes hable for any mjury not resulting in death. Yet, this view of Roe glosses over the profound difference between a motherchild relationship and a mother-fetus relationship. Adoption of this view would unduly burden pregnant women by inaking them the guarantors of fetal health. Gestational surrogate mothers have the same interests in their autonomy as other pregnant women and should enjoy the same protections.

\section{B. Traditional Applications of Parent-Child Tort Immunity}

If tort law were to recognize a duty of care for pregnant women, or for surrogate mothers in particular, the doctrine of parent-child tort immurnty would be significant in determining ultimate liability. Immunity doctrine recognizes the commission of a tort, but excuses hability because of special circumstances, such as the existence of a parent-child relationship.

The parental tort immumity doctrine was established in the United States by a "great trilogy" 59 of cases around the turn of the century. In the first of these cases, Hewlette v. George, ${ }^{60}$ the Mississippi Supreme Court held that a minor child could not recover compensatory damages against the estate of her mother. The plaimtiff had been wrongfully confined in an insane asylum while under the care and control of her mother. Although the Court acknowledged the child's injuries, it would not recognize a cause of action. Justice Woods wrote: "The peace of society, and of the families composing society ... forbid to the minor child a right to appear $\mathrm{m}$ court in the assertion of a claim to civil redress for personal injuries suffered at the hands of the parent." 61

The issue of parental tort immumity was revisited twelve years later in McKelvey v. McKelvey, ${ }^{62}$ in which the Tennessee Supreme Court relied extensively on the reasoning im Hewlette to deny the plaintiff a cause of
57. See id. at 158 .
58. See id. at 163.
59. Hansbrough, supra note 29, at 321.
60. 9 So. 885 (Miss. 1891).
61. Id. at 887.
62. 77 S.W. 664 (Tenn. 1903). 
action against his father and stepmother for cruel and inhumane treatment. ${ }^{63}$ The court also analogized parental tort immunity to husbandwife immunity, ${ }^{64}$ even though spousal immunity can be distinguished because it is grounded in the common law notion of unity at marriage. ${ }^{65}$ Because a husband and wife were considered one entity until the Married Women's Acts, ${ }^{66}$ a suit by one spouse against the other was the equivalent of sumg oneself. ${ }^{67}$ However, the parent-child relationship was never defined in this way. In exchange for a duty to provide support, a parent was given custody and control of a child. However, parents and children were never considered an indivisible unit. ${ }^{68}$

The final case of the trilogy that fixed the doctrine of parental immunity was decided two years after McKelvey. In Roller v. Roller, ${ }^{69}$ the Supreme Court of Washington reversed a $\$ 2000$ compensatory award to a minor child who had been raped by her father. Even though the father had been convicted of rape and sent to prison, the court, relying on $\mathrm{Hewl}$ ette, refused to recognize any cause of action by a minor child for the tortious conduct of her parent. ${ }^{70}$ This court also cited public policy reasons for not allowing a claim:

The rule of law prohibiting suits between parent and child is based upon the interest that society has in preserving harmony in the domestic relations, an interest which has been inanifested since the earliest organization of civilized government, an interest inspired by the universally recognized fact that the inaintenance of harmonious and proper family relations is conducive to good citizenship, and therefore works to the welfare of the state. ${ }^{71}$

The Roller court gave no weight to the argument that the rape of a daughter by her father, and not the subsequent tort claim, was the cause of family disharmony. ${ }^{72}$

As courts began applying the parental tort immunity doctrine throughout the United States, different rationales were given to support these decisions. Along with the family harmony justification pronounced in Hewlette, the Roller court also stated that the financial welfare of the

63. See id.

64. See id. at 665 . (1990).

65. See Isabel Wingerter, Note, Parent-Child Tort Immunity, 50 LA. L. REV. 1131, 1134

66. See William E. McCurdy, Property Torts Between Spouses and Use During Marriage of the Matrimonial Home Owned By the Other, 2 VILL. L. REv. 447, 449 (1957).

67. See, e.g., Thompson v. Thompson, 218 U.S. 611, 614 (1910); Kelley v. Kelley, 153 A. 314, 315 (R.I. 1931). See generally KEETON, supra note 38, § 122, at 901-04.

68. See KEETON, supra note 38 , § 122, at 904.

69. 79 P. 788 (Wash. 1905).

70. See id. at 789.

71. Id. at 788 .

72. See id. at 788-89. 
other minor children in the family cannot be coinpromised in favor of one child in particular. ${ }^{73}$ The court was also concerned with the possibility that "the parent would become heir to the very property which had been wrested by the law from him."74 For example, a father ordered to compensate his son for the father's tortious conduct would get that money back should the son die intestate before he inarried or had children of his own. Other courts addressed the problems of potential collusion or fraud between parent and child, especially when the parent is imsured. ${ }^{75}$ Another justification was the need for parents to control and discipline their children without fear of a lawsuit. ${ }^{76}$

Over the years, the harshness of the rule was amehorated in many states through a variety of exceptions. Because the doctrine was designed to protect family harmony, the dissolution of the family relationship made the doctrine inapplicable in soine cases, including emancipation of the minor, ${ }^{77}$ death of either party, ${ }^{78}$ temporary abandonment of the child by the parent, ${ }^{79}$ circumstances in which the child was not in the custody and control of the parent when the tort occurred, ${ }^{80}$ and parental abdication of parental responsibility. ${ }^{81}$

73. See id. at 789.

74. Id.

75. See, e.g., Barlow v. Iblings, 156 N.W.2d 105, 110 (Iowa 1968).

76. See, eg., Small v. Morrison, 118 S.E. 12, 15 (N.C. 1923) (holding that public policy considerations "discourage causes of actions that tend to destroy parental authority and to undermine the security of the home").

77. See, eg., Martinez v. Southern Pac. Co., 288 P.2d 868, 873 (Cal. 1955) (stating that an unemancipated child could not sustain a tort claim against her father); Weinberg v. Underwood, 244 A.2d 538, 539 (N.J. Super. 1968) ("[O]nce the child is legally emancipated the State has no strong interest in maintaining the harmony of the family unit.").

78. See, eg., Thurman v. Etherton, 459 S.W.2d 402, 403 (Ky. 1970) ("The family status is altered ... when the parent dies, and the public pohicy considerations supporting the doctrine of potential immunity are no longer controlling."); Logan v. Reaves, 354 S.W.2d 789, 791 (Tenn. 1962).

79. Intentional or wanton imjury to a child by a parent may constitute temporary abandonment. See, e.g., Attwood v. Estate of Attwood, 633 S.W.2d 366, 370 (Ark. 1982) (finding that father's drunk driving was wilful and wanton conduct for which a child can pursue an action against father's estate); Mahnke v. Moore, 77 A.2d 923, 926 (Md. 1951) (permitting child to maintain an action where father is guilty of acts that show complete abandonment of the parental relationship); Cowgill v. Boock, 218 P.2d 445, 453 (Or. 1950) (en banc) (allowing unemancipated minor to maintain an action against parent for a wilful or malicions personal tort).

80. See, e.g., Buffalo v. Buffalo, 441 N.E.2d 711, 712 (Ind. Ct. App. 1982) (refusing to preclude suit against noncustodial father arising from a dog attack); Bondurant v. Bondurant, 386 So. 2d 705, 706 (La. Ct. App. 1980) (finding no procedural bar to children's recovery against father where parents were divorced and mother was awarded sole custody); Fugate v. Fugate, 582 S.W.2d 663, 669 (Mo. 1979) (finding parent not immune from suit when she does not have primary, general custody of minor).

81. See, eg., Hoffman v. Tracy; 406 P.2d 323, 327 (Wash. 1965) (finding that mother who drove drunk abdieated parental responsibility and can be sued by child). 
Courts have also looked to the type of activity that resulted in the injury. Activities not central to the parent-child relationship were often excepted from the doctrine. These exceptions include actions that arose from neghigent driving of a parent, ${ }^{82}$ from a breach of duty by the parent owed to the general public, ${ }^{83}$ and from an employment activity unrelated to parental duties. ${ }^{84}$

Some courts have viewed hability imsurance as a factor that would make the immunity doctrine inapphicable rather than as a justification for the doctrine. ${ }^{85}$ Courts have reasoned that family harmony would not be disrupted nor would family funds be depleted if the claim is paid by a third party, such as an insurance company. ${ }^{86}$ Courts have also made an exception for third parties who seek contribution from a parent whose neghigence contributed to the child's mjury. ${ }^{87}$ In addition, immunity may be held inapplicable to some statutory causes of action. ${ }^{88}$

\section{Modern Treatment of Immunity}

The previous section shows that for over seventy years courts applied the parental tort immunity doctrine while contmually chipping away at it. In 1963, the Wisconsin Supreme Court abrogated the doctrine in Goller v. White. ${ }^{89}$ In that case, the court held that a foster father was liable to a boy in his care for injuries that resulted from a tractor accident. However, the court did carve out exceptions to the abrogation.

82. See, e.g., Ooms v. Ooms, 316 A.2d 783 (Conn. 1972) (finding statutory abrogation in motor vehicle negligence actions); Unah ex rel. Unah v. Martin, 676 P.2d 1366, 1370 (Okla. 1984) ("Parental immunity in vehicular negligence cases has no rational basis under present circumstances."). But see Frye v. Frye, 505 A.2d 826 (Md. 1986) (holding that any exceptions for vehicular negligence must coine from legislature).

83. See, e.g., Cummings v. Jackson, 372 N.E.2d 1127, 1128 (I1l. Ct. App. 1978) (holding that child, hit by car because of driver's obstruction of view, has cause of action against inother who failed to keep trces trimmed); Grivas v. Grivas, 496 N.Y.S.2d 757, 760-61 (App. Div. 1985) (finding that mother who left lawnmower unattended and running could be sued by anyone harmed, including child, but holding mother's failure to instruct child on lawnmower usage not actionable).

84. See, e.g., Signs v. Signs, 103 N.E.2d 743, 748 (N.Y. App. Div. 1952) (allowing child to maintain a cause of action against father and his partner for injuries resulting from negligent maintenance of a gasoline pump used for partnership business); Borst v. Borst, 251 P.2d 149, 156 (Wash. 1952) (en banc) (holding that a child injured by parent's reckless truck driving was in the course of employment, therefore, child could maintain suit); Felderhoff v. Felderhoff, 473 S.W.2d 928, 933 (Tex. 1971).

85. See, e.g., Rousey v. Rousey, 499 A.2d 1199, 1202 (D.C. App. 1985); Sorenson v. Sorenson, 339 N.E.2d 907, 914-15 (Mass. 1975). But see Owens v. Auto Mut. Indein. Co., 177 So. 133, 136 (Ala. 1937).

86. See, e.g., Sorenson, 339 N.E.2d at 914; Briere v. Briere, 224 A.2d 588, 591 (N.H. 1966).

87. See, e.g., Walker v. Milton, 268 So. 2d 654 (La. 1972); Goedkoop v. Ward Pavement Corp., 378 N.Y.S.2d 417 (App. Div. 1976).

88. See, e.g., Ooms v. Ooms, 316 A.2d 783, 785 (Conn. 1972); Thelen v. Thelen, 435 N.W.2d 495, 498 (Mich. Ct. App. 1989)

89. 122 N.W.2d 193 (Wis. 1963). 
A parent would still be immune from tort liability in two instances: "(1) where the alleged negligent act involves an exercise of parental autliority over the child; and (2) where the alleged negligent act involves an exercise of ordinary parental discretion with respect to the provision of food, clothing, housing, medical and dental services, and other care."90

Although the trend lias been toward either partial or total abrogation of the parental tort immumity doctrine, inany states still retain the doctrine. ${ }^{91}$ There is a great deal of variety among the states that liave recognized abrogation. Califorina, for example, in Gibson v. Gibson, ${ }^{92}$ constructed a "reasonably prudent parent" standard recognizing that "traditional concepts of negligence cannot be blindly applied."93 All states have carved out areas in which a parent is still immune from tort hability. These areas range from negligent supervision, ${ }^{94}$ to negligent entrustment of a dangerous instrumentahty, ${ }^{95}$ to exercise of parental authority. ${ }^{96}$ The scope of the immunity or the abrogation differs in each jurisdiction. ${ }^{97}$

In many states tlie immumity doctrine and the exceptions to its abrogation lave applied to those who stand in loco parentis ${ }^{98}$ as well as to actual parents. In a recent Michigan case, Thelen $v$. Thelen, ${ }^{99}$ a stepparent standing in loco parentis was permitted to assert the defense of parental immumity where a child was injured by a dog bite. 100

90. Id. at 198.

91. As of 1988,17 states retained the parental tort immunity doctrine. KEEToN, supra note 38, $\S 122$, at 907.

92. 479 P.2d 648 (Cal. 1971).

93. $I d$. at 652.

94. See, e.g., Holodook v. Spencer, 324 N.E.2d 338 (N.Y. 1974) (supervising children at play is discretionary and not actionable). Contra Thoreson v. Milwaukee \& Suburban Transp. Co., 201 N.W.2d 745 (Wis. 1972) (giving child who, left alone in house, wandered off and was hit by truck, cause of action against parents).

95. See, e.g., Nolechek v. Gesuale, 385 N.E.2d 1268, $1271-72$ (N.Y. 1978) (holding that entrusting a minor with a dangerous instrument is a discretionary decision within a parent's right), modified, Garrett v. Holiday Inns, Inc., 447 N.E.2d 717 (N.Y. 1983). Contra Howes v. Hansen, 201 N.W.2d 825, 832 (Wis. 1972) (finding a cause of action sinee parent's negligent supervision is not an exception to the abrogation of parental immunity); Horn v. Horn, 630 S.W.2d 70, 72 (Ky. 1982) (holding that a father who allowed his son to ride an unlicensed motorbike is not entitled to parental immunity).

96. See, e.g., Gross v. Sears, Roebuck \& Co., 386 A.2d 442, 445 (N.J. Super. Ct. App. Div. 1978); Sixkiller v. Summers, 680 P.2d 360, 362 (Okla. 1984).

97. See generally KEETON, supra note 38, § 122, at 907; Gail D. Hollister, Parent-Child Immunity: A Doctrine in Search of a Justification, 50 FORDHAM L. REV. 489, 528-32 (1982).

98. Those who act in loco parentis assune the role usually filled by a parent.

99. 435 N.W.2d 495 (Mich. Ct. App. 1989).

100. See id. at 496; see also Hush v. Devilbiss Co., 259 N.W.2d 170, 174 (Mich. Ct. App. 1977) (immunizing grandinother acting in loco parentis from suit based on negligent supervision). 
The questions arise whether children and fetuses are fundamentally different, and whether parent-child tort immunity doctrine and its abrogation apply to pregnant wonien and their fetuses. This doctrine may apply to gestational surrogate nothers while they are pregnant, whether they are viewed as parents, or, as Judge Parslow defined surrogate mothers in Johnson v. Calvert, as "foster parents."101 Since 1946, the right of children later born alive to recover for prenatal injuries caused by the neghigence of third parties has become firmly established.102

The future of the parental tort immunity doctrine is uncertain, and its focus is too narrow to protect adequately the rights of gestational surrogate mothers. Even if a surrogate mother's role as a parent is recognized, courts inay be reluctant to apply such a doctrine $\dot{\mathrm{n}} \mathbf{1}$ surrogate mother cases because none of the traditional rationales makes sense in a situation where the birth nother and the rearing mother are two different people. Because the child is being raised in another family, disruption of family harmony, collusion, and depletion of family assets would be irrelevant concerns. Only a formalistic apphication of the immunity doctrine would protect a surrogate nother froin tort liability for prenatal injuries. A pregnant woinan's right to bodily integrity and autononiy nuust rest on a broader liberty interest than the parent-child tort immunity doctrineespecially because the trend in many jurisdictions is toward abrogation of or restrictions on this type of immunity. Therefore, parental tort immunity may be a precarious doctrine on which to rest the rights of pregnant women, especially gestational surrogates.

\section{AUTONOMY AND THE LIMITS OF LIABILITY}

As the court in Stallman v. Youngquist ${ }^{103}$ noted, the recognition of a cause of action by a child against its mother for prenatal injuries would interfere with the inother's autononiy. ${ }^{104}$ Interests concerning autonomy and bodily integrity are also implicated in the cases that involve gestational surrogate inothers despite the existence of a contract that purports to circumscribe the autonony rights of the gestational surrogate mother. The bodily integrity of women falls within a category of social interaction that should be inalienable within the niarketplace. Professor Radin has offered a theory of market-inalienabilities that rests on the principle that soine activities and things should not be traded in the inarketplace.

101. See supra text accompanying notes 21-24.

102. See, e.g., Bonbrest v. Kotz, 65 F. Supp. 138 (D.D.C. 1946) (allowing viable fetus later born alive to recover for prenatal injuries). This position was rapidly adopted in all American jurisdictions. See KeEton, supra note $38, \S 55$, at 368.

103. 531 N.E.2d 355 (IIl. 1988). See supra text accompanying notes 48-55.

104. See Stallman, 531 N.E.2d at 358-59. 
Iteins are determined to be inalienable if they are central to our concepts of personhood and huinan flourishing. ${ }^{105}$ This theory rejects the transformation of people into commodities and attaclies inarket-inalienability to attributes and things that form "our understanding of identity and contextuality." 106 Bodily integrity is such an attribute:

Bodily integrity is an attribute and not an object. We feel discomfort or even insult, and we fear degradation or even loss of the value involved, when bodily integrity is conceived of as a fungible object .... Systematically conceiving of personal attributes as fungible objects is threatening to personhood, because it detaches from the person that which is integral to the person. ${ }^{107}$

Professor Radin examines surrogacy in light of this concept of human fiourishing and advocates the noncommodification of surrogacy. ${ }^{108}$ In a utopian world, all surrogacy would be inahenable because of the harm to our self-conception caused by the commodification of women's reproductive capacities and children. As a transitional stage in the real world, unpaid surrogacy would be permitted to fulfill the needs of those who feel that genetic offspring are necessary to be coinplete, as well as to fulfill the altruistic notives of some surrogate inothers. "To try to create an ideal world all at once would do violence to things people make central to themselves." 109

Although Radin beheves that the best solution in an non-ideal world is to permit unpaid surrogacy while not allowing paid surrogacy, she acknowledges the "double bind" that results froin conditions in our nonideal world. ${ }^{110}$ By creating inalienable riglits of autonomy, other rights are taken away (e.g., the right to contract freely):

[T] here is the possibility of even further oppression of poor or ignorant women, which inust be weighed against a possible step toward their liberation through economic gain from a new alienable entitlementthe double bind .... The availability of the surrogacy option could create hard choices for poor women .... It might be degrading for the surrogate to commodify her gestational services or her baby, but she might find this preferable to her other choices in life. ${ }^{111}$

Ultimately, Radin finds tlie market inalienability of surrogacy preferable to complete or partial commodification because of the "risk [of]

105. See Margaret J. Radin, Market-Inalienability, 100 HARV. L. REv. 1849, 1903 (1987); see also Margaret J. Radin, Property and Personhood, 34 STAN. L. Rev. 957 (1982).

106. Radin, Market-Inalienability, supra note 105, at 1906.

107. Id. at 1880-81.

108. See id. at 1921.

109. Id. at 1932.

110. See id. at 1930.

111. Id. 
conceiving of all woinen's personal attributes in inarket rhetoric, and because paid surrogacy within the current gender structure may symbolize that women are fungible babymakers . . . ."112

The theory of human flourishing that permeates Radin's work is relevant to the creation of a duty of care in the tort context. However, although protection of the bodily integrity rights of a surrogate mother necessarily limits her freedoin to contract and produces the "double bimd," this problem does not exist in the tort situation. State coercion through the imposition of a duty of care (not a contract to which the surrogate mother was a willing party) circumscribes the surrogate mother's autonomy.

\section{A. Medical Decisions}

Pregnant women face many medical decisions throughout their pregnancies that are left to the individual pregnant woman. The same choices should be left to gestational surrogate mothers because these mothers have the same stake $m$ their bodily integrity as other pregnant women. The fact that a woman is genetically unrelated to the fetus she is carrying and does not intend to raise the child is an inadequate reason for delegatimg the right to make health care decisions to the contracting parents, health care professionals, or the courts. After-the-fact tort hability stemming from prenatal inedical decisions would impose too great a burden on those choices and would effectively limit a woman's ability to make her own health care decisions.

1. Abortion. In 1973, the U.S. Supreme Court recognized a woman's constitutional right to have an abortion prior to the viability of the fetus. ${ }^{113}$ Surrogacy contracts typically contain clauses that shift the abortion decision from the surrogate mother to the intended rearing parents. ${ }^{114}$ These provisions usually delineate the choice to abort and the choice not to abort. ${ }^{115}$

Recall the hypothetical at the beginning of this Note. Suppose that Gloria Simmons, the gestational surrogate mother, is now ten weeks into her pregnancy. Henry and Wendy have decided that they no longer want to stay together after seven years of marriage, and they certainly do not want a baby to comphicate their situation. Can the Martins force

112. Id. at 1935.

113. See Roe v. Wade, 410 U.S. 113 (1973).

114. Thomas W. Mayo, Medical Decision Making During a Surrogate Pregnancy, 25 Hous. L. REV. 599, 609-10 (1988).

115. Id. at 610 . 
Gloria to have an abortion? If Gloria refuses, is she hable to the Martins or to the subsequently born child?

Although an abortion decision like Gloria's was not at issue in the Baby $M$ case, ${ }^{116}$ the New Jersey Supreme Court nevertheless said in dicta that such provisions would violate the constitutional right of abortion or procreation. ${ }^{117}$ It is unimaginable that specific performance ordering a woman to undergo or not to undergo an abortion would be ordered by a court. However, the award of money damages is an unresolved issue. Professor Mayo analogizes this abortion scenario with the racial discrimmation cases of Shelley v. Kraemer ${ }^{118}$ and Barrows v. Jackson. ${ }^{119}$ In Shelley, the Supreme Court refused to enforce a racially restrictive covenant on property. Court enforcement of a private agreement that discriminated on the basis of race would be state action that violated the Fourteenth Amendment. ${ }^{120}$ In Barrows, the court refused to award damages for breach of a racially restrictive covenant using the same reasoning that it used in Shelley. ${ }^{121}$ Professor Mayo asserts: "If the analogy between state ordered racial discrimination and active state interference with first trimester abortions is accepted, the logic of Barrows is clear: with respect to abortions, as with racial discrimination, a state may not penalize conduct that it lacks the power to forbid."122

In Planned Parenthood v. Danforth, ${ }^{123}$ the Supreme Court struck down a statute that would have required woinen to get spousal consent to obtain an abortion. The Court held that the state could not delegate a right that the state itself did not have. ${ }^{124}$ Shelley, Barrows, Roe, and Danforth, taken together, suggest that a gestational surrogate's right to choose whether or not to have an abortion would be unduly burdened by the potential of civil hability that might stem froin that decision. "The Shelley-Barrows-Roe-Danforth line of cases does accomplish one thing: It demonstrates that, in the absence of a contract (or, if the surrogate mother is unable to contract away her abortion rights), the state probably lacks the power to award damages to the biological father in tort."12s

116. In re Baby M, 537 A.2d 1227 (N.J. 1988).

117. Almost all commentary on the subject is in agreement with the New Jersey Court. See Mayo, supra note 114 , at 611 .

118. 334 U.S. 1 (1948) (holding state enforcement of racially restrictive covenants unconstitutional).

119. 346 U.S. 249 (1953) (voiding an award of monetary damages against a property owner who breached a racial covenant as being violative of the Fourteenth Amendment).

120. See Shelley, 334 U.S. at 20.

121. See Barrows, 346 U.S. at 254.

122. Mayo, supro note 114, at 617.

123. 428 U.S. 52 (1976).

124. See id. at 69.

125. Mayo, supra note 114, at 618 n.75. 
The child born to Gloria Simmons would also be without a cause of action. Courts have always considered a child better off being born rather than being aborted. ${ }^{126}$

2. Other Medical Decisions. A variety of inedical care decisions (other than the abortion decision) that arise during pregnancy may affect the health of both mother and fetus. An individual's right to refuse medical treatment is a firmly established tenet of American law: "Every human being of adult years and sound mind has a right to determine what shall be done with his own body; and a surgeon who performs an operation without his patient's consent commits an assault, for which he is liable in damages."127 The rights of gestational surrogate mothers in managing their pregnancies are complicated by the imterests of the fetus, the biological parents, and the state.

Suppose tliat Gloria Simmons goes into labor, and while slie is connected to a fetal momitor, the doctor notices that the fetal lieartbeat lias decelerated. The doctor suggests that Gloria dehiver by cesarean section because the fetus may be im distress. Slould Gloria, faced witl an invasive surgical procedure, be permitted to choose which course to follow? If slie refuses to consent to the cesarean, will the after-born child have a cause of action in tort if the child sustains injuries due to Gloria's election of a vaginal delivery?

Some commentators liave suggested that these decisions, including regular doctor visits, pregnancy-related diagnosis and treatment, and adlierence to doctor's orders, should be made by the biological parents because they are the "real" parents. ${ }^{128}$ However, these cominentators neglect to take into account the interests of the gestational surrogate notler in lier bodily imtegrity. At tlie point im which the ouly contribution of the intended rearing parents is their genetic material and financial support, the motlier's rights should override these interests. ${ }^{129}$ The health and lifestyle of the surrogate motlier are gravely affected by a pregnancy. Therefore, a gestational surrogate motler must liave all the riglits of any otlier pregnant woinan im making medical decisions.

Soine courts liave overridden a pregnant woman's riglit to refuse particular medical treatments to protect the life and health of the fetus.

126. See, e.g., Gleitman v. Cosgrove, 227 A.2d 689, 692 (N.J. 1967) ("The infant plaintiff would have us measure the difference between his life with defects against the utter void of nonexistence, but it is impossible to make such a determination.").

127. Schloendorff v. Society of N.Y. Hosp., 105 N.E. 92, 93 (N.Y. 1914).

128. See, e.g., John J. Mandler, Note, Developing a Concept of the Modern "Family": A Proposed Uniform Surrogate Parenthood Act, 73 GEO. L.J. 1283, 1312 (1985).

129. See supra text accompanying notes $32-36$. 
Although the medical profession traditionally treated the pregnant woman and her fetus as one patient, advances im our knowledge of environmental effects and maternal conduct on fetuses have led to a new concept of the fetus as a separate and distimct patient. ${ }^{130}$ Increased ability to treat fetuses before birth has also inspired the fetal rights inovement. ${ }^{131}$ This concept of the fetus as a patient has led to state intervention in the management of individual pregnancies. Intervention has been inost prevalent in the area of judicially ordered, forced cesarean sections. ${ }^{132}$ Although a number of lower courts have ordered this invasive procedure, ${ }^{133}$ only two appellate decisions have been reported. ${ }^{134}$ In the more recent decision, In re A.C. ${ }^{135}$ the District of Columbia Court of Appeals held that "in virtually all cases the question of what is to be done is to be decided by the patient-the pregnant woman-on behalf of herself and the fetus." 136 In this unusual case, a terminally ill pregnant woman was forced to undergo a cesarean section against her wishes to atteinpt to save the life of her twenty-six week old fetus. The mother wanted to try to stay alive until the twenty-eighth week when the fetus wonld have a much better chance of survival. She had previously agreed to submit to a cesarean section when the fetus reached that level of maturity. As her condition worsened, the hospital requested a declaratory judgment from the trial

130. See Developments in the Law - Medical Technology and the Law, 103 HARV. L. REv. 1519, 1556 (1990) [hereinafter Medical Technology and the Law].

131. See Ira M. Eliman ET al., Family Law 1152 (2d ed. 1991); William Ruddick \& William Wilcox, Operating on the Fetus, HASTINGS CENTER ReP., Oct. 1982, at 10.

132. Forced cesarean sections have been very controversial and have spawned reams of coininentary. See, e.g., George J. Annas, Forced Cesareans: The Most Unkindest Cut of All, HASTINGS CENTER ReP., June 1982, at 16; Martha A. Field, Controlling the Woman to Protect the Fetus, 17 LAw MED. \& Health CARE 114 (1989); Janet Gallagher, Prenatal Invasions \& Interventions: What's Wrong With Fetal Rights, 10 HaRv. WoMEN's L.J. 9 (1987); Jeanne Guillenin, Babies By Cesarean: Who Chooses, Who Controls?, Hastings CenTER REP., June 1981, at 15; Dawn E. Johnsen, The Creation of Fetal Rights: Conficts with Women's Constitutional Rights to Liberty, Privacy, and Equal Protection, 95 YALe L.J. 599 (1986); Lawrence J. Nelson et al., Forced Medical Treatment of Pregnant Women: Compelling Each to Live as Seems Good to the Rest, 37 HASTINGS L.J. 703 (1986); Stewart G. Pollock, Life and Death Decisions: Who Makes Them and By What Standards?, 41 RuTGers L. REV. 505 (1989); John A. Robertson, Procreative Liberty and the Control of Conception, Pregnancy, and Childbirth, 69 VA. L. Rev. 405 (1983); Note, Rethinking (M)otherhood: Feminist Theory and State Regulation of Pregnancy, 103 HARV. L. REV. 1325 (1990).

133. A national survey in the 1980 s reported that over a five-year period, 21 court orders had been sought to compel treatment of pregnant women. Of these, 15 were for cesarean sections, 13 of which were granted. Veronica E.B. Kolder et al., Court-Ordered Obstetrical Interventions, 316 NEw ENG. J. MED. 1192, $1192-93$ (1987); see also Susan Goldberg, Medical Choices During Pregnancy: Whose Decision Is It Anyway?, 41 Rutgers L. REV. 591, 609 n.135 (1989) (citing 12 cases of compelled cesarean sections).

134. Jefferson v. Griffin Spalding County Hosp. Auth., 274 S.E.2d 457 (Ga. 1981) (per curiam) (denying motion to stay court-ordered cesarean); In re A.C., 573 A.2d 1235 (D.C. App. 1990) (en banc).

135. 573 A.2d 1235 (D.C. App. 1990) (en banc).

136. Id. at 1237 . 
court. The court ordered a cesarean section to be performed, and a three-judge motions division denied a stay of the order. The surgery was performed, and both mother and child died. ${ }^{137}$ The en banc court reversed, citing the primciple of informed consent, which, "rooted in the concept of bodily integrity, is ingrained in our common law."138 The court also noted the common law rule that a person has no duty to rescue another. ${ }^{139}$

The American College of Obstetricians and Gynecologists (ACOG) has also recognized the importance of allowing pregnant women to make their own medical choices:

Obstetricians should refrain from performing procedures that are unwanted by a pregnant woman. The use of judicial authority to implement treatment regimens im order to protect the fetus violates the pregnant woman's autonomy. Furthermore, mappropriate rehance on judicial authority may lead to undesirable social consequences, such as the criminalization of noncompliance with medical recommendations. ${ }^{140}$

Fetal rights advocates disagree. They contend that once a woman "waives" her right to an abortion by choosing to carry the fetus to term, she has the responsibility of assuring the health of the child. ${ }^{141}$ Preference for fetal rights over maternal rights is often justified by analogy to tort law cases $\mathrm{n} 1$ which third parties are involved. ${ }^{142}$ In the 1946 case of Bonbrest v. Kotz, ${ }^{143}$ a court, for the first time, allowed recovery for reasonably foreseeable prenatal injuries to a child subsequently born alive. All American jurisdictions now recognize such a cause of action. However, the only court ever to apply this tort doctrime to a mother rather than a third party was the Grodin court. ${ }^{144}$ Some commentators support the Grodin position. For example, Professor Robertson contends that a "viable fetus acquires rights to have the mother conduct her life im ways that will not ijure it."145 These rights can be asserted by forced medical intervention or after-the-fact tort hability.

Forced inedical procedures, or other coercive methods to msure benefits to another, have been implemented only im the pregnancy context. In these cases, the rights of a fetus have been elevated over those of

137. Id.

138. Id. at 1243.

139. See id. at 1244.

140. Patient Choice: Maternal-Fetal Conflict, ACOG Comm. Op. No. 55 (1987), quoted in ELLMAN, supra note 131, at 1152 .

141. See Robertson, supra note 132, at 450.

142. See id. at 439.

143. 65 F. Supp. 138 (D.D.C. 1946).

144. 301 N.W.2d 869 (Mich. Ct. App. 1980).

145. Robertson, supra note 132 , at 438 . 
the already born. For example, in November 1990, the Illinois Supreme Court refused to order tests on healthy twin boys to determine their suitability as bone marrow donors for their thirteen year old half-brother over the objections of their mother. ${ }^{146}$ The thirteen year old died of leukemia because he was unable to get a bone marrow transplant. ${ }^{147}$ In McFall v. Shimp, ${ }^{148}$ the cousin of a fatally ill man was the only known compatible bone marrow donor. Yet, a Pennsylvania judge, while finding the cousm's behavior repugnant, refused to order the cousm to undergo the bone marrow donation procedure. "For a society . . . to sink its teeth into the ... neck of one of its members and suck from it sustenance for another member, is revolting to our hard-wrought concepts of jurisprudence." 149 These courts have rested their decisions on the common law principle that there is no legal duty to rescue. ${ }^{150}$

A recent appellate court decision in New York that allowed a mother to refuse a blood transfusion was upheld by New York's highest court. ${ }^{151}$ The state argued that the woman should be forced to submit to the transfusion on behalf of her newborn because the mother's death would constitute parental abandonment. ${ }^{152}$ The appellate court eliminated this factor from consideration, holding that the right to refuse treatment is virtually absolute and should not be balanced aganist other considerations. ${ }^{153}$

Forcing pregnant women to undergo mvasive medical procedures or face civil hability elevates medical "advice" to the level of legally enforceable orders. Although modern obstetrics/gynecology professionals have made important contributions to maternal and fetal health, the health care profession has also been responsible for prescribing drugs like $\mathrm{DES}^{154}$ and thalidomide ${ }^{155}$ to pregnant women. Iatrogemic ${ }^{156}$ medicine

146. See Boy at Center of Suit for a Marrow Donor Is Dead of Leukemia, N.Y. TIMES, Nov. 20, 1990, at B9.

147. Id.

148. 10 Pa. D. \& C.3d 90 (1978).

149. Id. at 92; see also In re Application of George, 630 S.W.2d 614 (Mo. Ct. App. 1982) (refusing to force putative father to undergo a blood test to aid son with leukemia).

150. Medical Technology and the Law, supra note 130, at 1570.

151. See Fosmire v. Nicoleau, 551 N.E.2d 77 (N.Y. 1990), aff'g 536 N.Y.S.2d 492 (N.Y. App. Div. 1989).

152. Id. at 83.

153. See id. at 84.

154. DES (Diethylstilbestrol) was prescribed to pregnant women as an anti-miscarriage drug in the 1940s, 1950s, and 1960s even though its effectiveness was unproven. Daughters boru to women who had taken DES while pregnant liave an unusually high rate of vaginal cancer. Even after the inedical community became aware of the problems with DES in the 1970s, the drug was used experimentally as a "morning-after" pill on young women who were unaware of its dangers. GiNA Corea, The Hidden Malpractice: How American Medicine Treats Women as Patients AND Professionals 242-52 (1977). 
remains a significant problem, and women must be allowed to assess the advantages and risks of treatment, and decide for themselves which risks they are willing to take.

Some forms of doctor's advice do not entail direct mvasion of the body of a pregnant woman, but do impact her lifestyle choices. For imstance, suppose our hypothetical gestational surrogate mother, Gloria, is in her sixth month of pregnancy and has been told by her doctor that she is suffering from severe preeclampsia. ${ }^{157}$ Because this condition often leads to premature labor and increased morbidity and mortality of newborns, ${ }^{158}$ the doctor, with the support of Wendy and Henry, has ordered Gloria to spend the remainder of her pregnancy in bed. Gloria, who has three other children, refuses to give up her nursing position because she needs the money to support her family. If the baby that Gloria is carrying is born prematurely and suffers lung problems as a result, should the child be able to recover from Gloria im a tort action?

Limiting Gloria's activities, especially employment, places an undue burden on her autonomy. Such a duty of care to a fetus places the fetus's interests above those of the mother and her existing children.

Although fetal health is a legitimate concern, it is outweighed by a woman's fundamental right to bodily integrity and personal autonomy. A mother's medical care choices may produce tragic results in a given case. However, the cost to society of preventing such tragedies would be the subjugation of individuals to an unbounded tyranny of technology and medical science. ${ }^{159}$ The same policy considerations and fundamental rights that are at stake for mothers in general also apply to gestational surrogate mothers during their pregnancies. The genetic link to a fetus is not what creates autonomy rights in a mother; a gestational surrogate has as compelling an interest in her bodily integrity as any other mother. Tort hability for making the "wrong" medical decision would place too

155. Thalidomide was widely prescribed to pregnant women in many countries as an anti-nausea drug in 1960-1961. The drug was distributed for investigational use in the Urited States. The effects of thalidomide on fetuses were tragic. Thalidomide babies were born with limbs that were reduced or nonexistent, as well as a range of other birth defects. One dosage was enough to cause gross abnormalities. Before the drug was discontinued, thalidomide produced thousands of victims. Max Sherman \& Steven Strauss, Thalidomide: A Twenty-Five Year Perspective, 41 Foon DRug Cosm. L.J. 458-61 (1986).

156. Iatrogenic illness is "an alteration in the state of health of a patient during the course of medical treatinent . . . which is the result of the procedure rather than any underlying disease or ilhiess." William R. Anderson, Iatrogenic Death and Injury, Trauma, Aug. 1987, at 9, 10.

157. Preeclampsia is pregnancy-induced hypertension that results from spasin of the end arteries. See John L. Duhring, Nutritional Requirements of Pregnancy, in Pregnancy, Childbirth, AND Parenthood 50 (Paul Ahmed ed., 1981).

158. Id. at 50-51.

159. Medical Technology and the Law, supra note 130, at 1572. 
great a burden on the gestational surrogate mother and would, in effect, make the exercise of free choice impossible.

\section{B. Nutrition, Alcohol, and Tobacco}

Prenatal care is extremely important to the health of a fetus. Among the inost vital aspects of prenatal health is the quality of nutritional intake. ${ }^{160}$ Naturally, a fetus only receives what its mother ingests. A poor maternal diet may result in a number of health problems for the newborn. ${ }^{161}$ Vitamin and mineral deficiencies, ${ }^{162}$ as well as excess ingestion of certain vitamins, can cause a range of serious inedical conditions. ${ }^{163}$

At least one judge has recognized the importance of nutrition in pregnancy and tried to burden the fundamental procreation right of a defendant to prevent potential harm to a fetus. ${ }^{164}$ In People v. Pointer, the trial judge was faced with a defendant who was a strict adherent to a macrobiotic diet ${ }^{165}$ regime. She was convicted of child endangerment because she kept her small children on the same diet. The judge imposed a restriction on her probation that she not conceive another child because of potential danger to a fetus in utero. The appellate court reversed, holding that such a burden was unconstitutional and would be coercive of abortion. ${ }^{166}$ However, the appellate court did leave open the door for forced prenatal care as a less burdensome alternative. ${ }^{167}$

Not surprisingly, in the context of the gestational surrogacy, soine intended rearing parents would like to control the nutritional intake of the gestational surrogate mother. However, this type of control, either directly or through after-the-fact tort hability, implicates the same fundamental rights as coercive inedical care. Making a pregnant woman responsible for every morsel she eats or fails to eat is not only impractical,

160. Duhring, supra note 157 , at $40-41$.

161. Inadequate diet may cause reduced brain weight, smaller head circumference, impairment of fetal brain development, prematurity, and permanent mental deficiency. Hansbrough, supra note 29 , at 331.

162. Iodine deficiency can cause goiter or cretinism. Lack of vitamin D or calcium may cause rickets. Lack of vitamin A can cause underdeveloped major organs and other defects. Hydrocephaly, which in turn causes retardation, results from deprivation of vitamin B12. Riboflavin deficiency may cause malocelusion of the jaws and teeth and possibly a cleft palate. Id. at 332 .

163. Excess ingestion of fat-soluble vitamins, especially $A$ and $D$, may cause congenital malformations in newborns. Duhring, supra note 157, at 43.

164. See People v. Pointer, 199 Cal. Rptr. 357 (Ct. App. 1984).

165. A macrobiotic diet consists mainly of vegetables and grains. WEBSTER's ENCYCLOPEDIC UNABRIDGED DICTIONARY OF THE ENGL1SH LANGUAGE 860 (1989).

166. See Pointer, 199 Cal. Rptr. at 365.

167. See id. at 366 . 
but relegates the woman to the role of fetal container whose sole responsibility is to produce the perfect baby.

The most persuasive argument for limiting a pregnant woman's right of self-determination is im the area of alcohol and tobacco use because they are inherently dangerous substances that harm adults as well as fetuses. However, as long as these products remain legal im the Umited States, monitoring their use by pregnant women would constitute a greater harm. Regulating maternal behavior in an otherwise legal pursuit would justify regulation of and civil hability for any maternal activity that may affect fetal health.

The effects on fetuses of moderate alcohol consumption during pregnancy are widely disputed im the medical community. ${ }^{168}$ However, heavy alcohol consuniption during pregnancy is known to have serious and lasting effects on the health of newborns, including physical abnormalities, retarded growth, and developmental delay. ${ }^{169}$ Excessive drinking often results im a child born with Fetal Alcohol Syndrome (FAS). ${ }^{170}$

Tobacco is also known to have deleterious effects on fetuses. The micotime that a pregnant woman inhales crosses the placcnta, and the fetus may develop a incotine dependence. 171 The most common medical probleins associated with newborns of smokers are prematurity, growth retardation, and low birth weight. ${ }^{172}$ Although alcohol and tobacco can cause serious health problems for fetuses as well as adults, their use remains legal in the United States.

Even though alcohol consunption is legal, driving while under the influence of alcohol is not. Because drunk driving is an illegal activity, tort hability stemming from this activity would not impose on a pregnant woman's autonomy. She is not free to drive under the influence of alcohol, so recovery by an injured child cannot be a burden in a choice she is not otherwise free to make. Therefore, a child should be able to recover from her mother for prenatal injuries caused by the mother's drunk driving.

168. See Field, supra note 132, at 119 n.45.

169. Hansbrough, supra note 29 , at $332-33$.

170. Health problems associated with FAS include prenatal and postnatal growth retardation, cardiac defects, craniofacial deformities, impaired joint inobility, central nervous system abnormalities, and microcncephaly with mental retardation. Field, supra note 132, at 119.

171. David W. Martin, Alcohol and Drug Abuse in Pregnancy: Information for Patients, in Pregnancy, Childitrth, ANd Parenthood, supra note 157, at 139, 142.

172. Hansbrough, supra note 29, at 333 . 


\section{Illegal Drugs}

Suppose that Gloria Simmons is progressing in her surrogate pregnancy, but she habitually sinokes crack. Should she be hable to the fetus she is carrying if the child is born with injuries due to crack use? Liability stemming froin injury caused by illegal activity is inherently different than hability of gestational surrogate nothers arising from a legal activity. The specter of tort hability inay restrict pregnant woinen, in general, and gestational surrogate inothers, in particular, froin inaking choices that we regularly allow others to make. However, because we prohibit all people from using certain drugs, imposing tort hability for injuries caused by the ingestion of controlled substances does not impose on a pregnant woman's autonony. Regardless of the tort possibilities, smoking crack is not a choice that Gloria is otherwise free to inake.

The use of illegal drugs by pregnant women is becoming a widespread problem ${ }^{173}$ and can have devastating effects on fetuses. ${ }^{174}$ Coininentators have written extensively about maternal drug use, offering a variety of solutions, including better treatment for maternal abusers ${ }^{175}$ and greater regulation of pregnant women. ${ }^{176}$

173. See Kristen R. Lichtenberg, Comment, Gestational Substance Abuse: A Call for a Thoughtful Legislative Response, 65 WASH. L. REv. 377, 379 n.17 (1990) ("In the United States in 1989, 375,000 infants will have been exposed prenatally to illegal drugs.").

174. For example, use of cocaine, especially in its potent "crack" form, during gestation may cause oxygen deprivation or inalformations of the urogenital, cardiac, and central nervous systens. Fetuses exposed to crack are also at risk of having strokes at birth, which can lead to brain damage. Cocaine can cause permanent neurological problems that affect motor skills, reflexes, and coordination. Fetuses exposed to cocaine usually have lower birth weights and snialler head circumferences than other babies. Id. at 379-80; see also Janet $\mathrm{R}$. Fink, Effects of Crack and Cocaine on Infants: $A$ Brief Review of the Literature, 24 Clearinghouse Rev. 460 (Spec. Issue 1990).

175. Many commentators have advocated increased treatment programs to conbat gestational drug abuse rather than crimimal or civil sanctious. See, e.g., George J. Annas, Pregnant Women as Fetal Containers, Hastings Center Rep., Dec. 1986, at 13; Dawn E. Johnsen, From Driving to Drugs: Governmental Regulation of Pregnant Women's Lives After Webster, 138 U. PA. L. Rev. 179 (1989); Thounas B. Mackenzie et al., Case Studies: When a Pregnant Woman Endangers Her Fetus, Hastings Center ReP., Feb. 1986, at 24; Kary Moss, Substance Abuse During Pregnancy, 13 HARV. WOMEN's L.J. 278 (1990); Emily M. Dargatz, Note, Legal Representation of a Fetus: The Mother and Child Disunion?, 18 CAP. U. L. REv. 591 (1989); Judith Kahn, Note, Of Woman's First Disobedience: Forsaking a Duty of Care to Her Fetus-Is this a Mother's Crime?, 53 Brook. L. REv. 807 (1987); Rebecca Manson \& Judy Marolt, Comment, A New Crime, Fetal Neglect: State Intervention to Protect the Unborn-Protection at What Cost?, 24 CAL. W. L. REv. 161 (1988); Bonnie I. Robin-Vergeer, Note, The Problem of the Drug-Exposed Newborn: A Return to Principled Intervention, 42 StAN. L. REv. 745 (1990); Notc, Maternal Rights and Fetal Wrongs: The Case Against the Criminalization of "Fetal Abuse", 101 HARv. L. REv. 994 (1988).

176. See, e.g., Tom Rickhoff \& Cuasil Cukjati, Protecting the Fetus from Maternal Drug and Alcohol Abuse: A Proposal for Texas, 21 ST. MARY's L.J. 259 (1990); Sam S. Balisy, Note, Matemal Substance Abuse: The Need to Provide Legal Protection for the Fetus, 60 S. CAL. L. REv. 1209 (1987). 
Civil child abuse laws have been extended to cover prenatal drug use, ${ }^{177}$ and positive toxicology of newborns can result in a neglect determination. ${ }^{178}$ In a New York case, In re Fathima Ashanti K.J., ${ }^{179}$ a child tested positive for cocaine at birth and exhibited health problems associated with prenatal drug ingestion. ${ }^{180}$ The court interpreted the state abuse laws to include the unborn, and mandated judicial imtervention for protection of a newborn.

States have also turned to their criminal laws, albeit with mixed results, to prosecute fetal abuse arising from illegal drug use. In Illinois, prosecutors pressed manslaughter charges against Melaine Green for allegedly using crack during her pregnancy that resulted in the death of her baby. The grand jury would not return an indictment. ${ }^{181}$ In Florida, however, a successful prosecution was brought against Jennifer Johnson. Johnson was charged with dehivery of an illegal substance to a minor. The prosecutor argued that dehvery occurred through the umbilical cord immediately after birth. ${ }^{182}$

Spending resources on civil neglect proceedings and prosecutions of pregnant women for fetal abuse instead of on treatment for drug addiction and prenatal care may not be the wisest public policy to insure the health of newborns. But because states already forbid people from using controlled substances, no autonomy rights are imphicated in permitting mjured children to recover for injuries that result from their mothers' gestational use of illegal drugs.

\section{CONCLUSION}

As long as gestational surrogate arrangements remain a legal means for infertile couples to acquire babies, the rights and responsibilities of the parties must be clearly defined to avoid conflict and litigation. The potential for psycliological harm to all the parties involved should a surrogate arrangeinent go awry is only exacerbated by vague legal rules witl indefinite outcomes. A bright-hine rule that prohibits tort recovery for injuries caused by legal maternal behavior would allow for predictable

177. See, e.g., Fla. Stat. ANN. § 415.503(9)(a) (West Supp. 1990) (defining "harm" to include drug dependency of newborn); MASs. GEN. LAwS ANN. ch. 119, § 51A (West Supp. 1990) (defining "abused child" to include one who is "physically dependent upon an addictive drug at birth"); see also supra note 6.

178. See In re Fathima Ashanti K.J., 558 N.Y.S.2d 447 (Fam. Ct. 1990).

179. Id.

180. Id.

181. Isabel Wilkerson, Jury in Illinois Refuses to Charge Mother in Drug Death of Newborn, N.Y. TIMES, May 27, 1989, at A10.

182. Tamar Lewin, Drug Use During Pregnancy: New Issue for the Courts, N.Y. TimES, Feb. 5, 1990, at A14. 
and fair results. It is true that some maternal behavior may cause injury to a fetus, and traditional tort doctrine can be interpreted to create a mother's duty to rescue a fetus because of the mother-fetus relationship. However, imposing a duty of care on pregnant woinen, including gestational surrogate inothers, places too great a burden on women's autonoiny. Making inothers the guarantors of fetal health would subordinate their entire hives to the interests of a fetus, placing fetal interests above the rights of woinen.

Disallowing actions in tort by the intended rearing parents on behalf of injured children, except in cases of illegal activities, may chill the number of surrogate agreeinents. Some potential genetic parents may not want to assume the risk of any potential adverse consequences to the fetus that result froin maternal conduct. This is not only understandable, but desirable. Intended rearing parents who enter into these arrangements inust recognize that they are dealing with women who have fundainental rights of autonoiny and bodily integrity. To prevent women from becoming mere fetal containers, the intended parents inust assume the risk that the gestational surrogate mother may exercise her rights in ways that place her interests in conflict with theirs.

New technologies and the old desire for genetic children will continually draw soine infertile couples toward gestational surrogacy. The law must respond by treating gestational surrogate mothers just like other pregnant women and by recognizing the autonoiny rights of all pregnant women. 